\title{
ANALISIS PEMANFAATAN APLIKASI GOJEK BERBASIS SISTEM INFORMASI GEOGRAFIS (PERSEPSI PELAYANAN GOJEK PADA MAHASISWA UINSU)
}

\author{
Anang Anas Azhar \\ Program Studi Ilmu Komunikasi, Fakultas Ilmu Sosial, UINSU \\ Jalan William Iskandar, Medan Estate, Percut Sei Tuan, Deli Serdang, 20371, Indonesia \\ Email: anangazhar@uinsu.ac.id
}

Diterima: 24 Februari 2020, Direvisi: 17 Maret 2020, Disetujui: 28 Maret 2020

\begin{abstract}
Abstrak
Manusia dan teknologi merupakan dua hal yang saling berkaitan yaitu sebagian manusia sebagai pencipta teknologi dan sebagian manusia lainnya sebagai pengguna teknologi. Berkembang dan lahirnya teknologi baru merupakan simbol kemajuan suatu negara karena merupakan suatu tolak ukur dari perkembangan suatu negara sebagai wujud inovasi. Penelitian ini bertujuan untuk mengetahui persepsi mahasiswa Ilmu Komunikasi Universitas Islam Negeri Sumatera Utara (UINSU) Medan mengenai kualitas pelayanan yang dimiliki aplikasi Gojek yang terdiri atas kenampakan fisik, reliabilitas, responsivitas, kompetensi, kesopanan, kredibilitas, keamanan, akses, komunikasi, dan pengertian. Metode yang digunakan pada penelitian ini adalah kuantitatif deskriptif dengan metode pengambilan sampel menggunakan Proportional Stratified Sampling dengan jumlah sampel sebanyak 72 orang mahasiswa. Hasil penelitian menunjukkan bahwa mahasiswa Ilmu Komunikasi Fakultas Ilmu Sosial UINSU Medan telah mempersepsikan aplikasi Gojek sebagai transportasi online yang bagus, baik dan kredible. Dapat dilihat dari hasil data penampakan fisik, reliabilitas, responsivitas, kompetensi, kesopanan, kredibilitas, keamanan, akses, komunikasi dan pengertian telah dinyatakan baik dan bagus oleh pengguna atau konsumen Gojek.
\end{abstract}

Kata Kunci: Persepsi, Kualitas Layanan, Transportasi, Gojek

\begin{abstract}
Abstrack
Humans and technology are interrelated, that is, some people as the technology creators while others as the users. The emergence and the advance of new technology are the symbols of the development of a country as it is set as a benchmark for the development of a country as a form of innovation. This study aims to determine the perception of the Communication Studies students of Sumatra Utara State Islamic University (UINSU) Medan related to the service quality of Gojek application. The services are physical appearance, reliability, responsiveness, competence, politeness, credibility, security, accessibility, affability, and mutual understanding. The method used in this research is the descriptive quantitative method in which the sampling method using the Proportional Stratified Sampling with a total sample of 72 students. The results show that the students had perceived the Gojek application as an excellent, satisfying and credible online transportation. It can be seen from the results of the statical analysis of the quality of the services have been stated as excellent and satisfying by the users or costumers.
\end{abstract}

Keywords: Perception, Service Quality, Transportation, Gojek. 


\section{PENDAHULUAN}

Manusia dan teknologi merupakan dua hal yang saling berkaitan yaitu sebagian manusia sebagai pencipta (pembuat) teknologi dan sebagian manusia lainnya sebagai pengguna teknologi. Perkembangan teknologi setiap saatnya semakin berkembang dengan pesat dan tidak terlepas dari peran manusia yang terus menerus menciptakan dan menyempurnakan teknologi. Hadirnya teknologi tidak terlepas dari kebutuhan manusia terhadap teknologi yang dapat membantu dan mempermudah manusia dalam kehidupan sehari-hari. Ponsel pintar, komputer, dan internet adalah teknologi revolusioner, tetapi tampaknya sebanding dengan dampaknya terhadap revolusi besar lainnya dalam komunikasi dan transportasi yang telah digunakan selama puluhan tahun terakhir.

Berkembang dan lahirnya teknologi baru merupakan simbol kemajuan suatu negara karena teknologi merupakan suatu tolak ukur dari perkembangan suatau negara sebagai wujud inovasi. Semakin banyak teknologi yang tercipta, berkembang, dan digunakan oleh masyarakat suatu negara, maka sudah pasti negara tersebut merupakan sebuah negara maju. Peran inovasi yang menonjol dalam pasar digital yang muncul di Indonesia menghadirkan tantangan baru bagi undang-undang dan kebijakan persaingan saat ini. Di bidang kebijakan persaingan, inovasi belum mengambil peran yang jelas dalam menyesuaikan peraturan atau pendekatan yang sesuai, pasar telah berupaya menyesuaikan diri dengan perubahan baru untuk memenuhi permintaan yang meningkat. Keadaan kebijakan saat ini diilustrasikan oleh pengembangan jaringan transportasi online seperti yang disediakan oleh transportasi online berbasis aplikasi.

Salah satu kebutuhan teknologi yang saat ini sangat dibutuhkan manusia adalah jaringan internet. Keberadaan internet telah membantu manusia dalam berbagai hal antara lain berkomunikasi, penggunaan smartphone, dan berbagai aplikasi yang ada didalam smartphone seperti aplikasi transportasi online.

Pelanggan layanan berbasis aplikasi smartphone bebas untuk mengatur perjalanan secara real time dengan penyedia layanan. Orang melihat layanan sebagai alternatif transportasi yang dapat melayani dengan cepat, fleksibel, responsif, dan mudah digunakan. Selain memberikan alternatif perjalanan yang menarik, layanan ini juga berpotensi mengurangi penggunaan kendaraan pribadi dan masalah lingkungan. Namun, manfaat tersebut tidak berlaku untuk semua tingkat pendapatan. Orang berpenghasilan rendah yang tidak memiliki ponsel cerdas atau tidak dapat menggunakan layanan akan tertinggal dan orang-orang yang bergantung pada angkutan umum konvensional akan kehilangan pangsa pasar.

Hal ini menimbulkan pertanyaan tentang respons pemerintah terhadap peraturan dan kebijakan yang tepat. Fenomena yang berkembang dari layanan penjemputan transportasi dalam kota online telah diterima secara luas dan dianut oleh orang Indonesia yang telah lama menunggu transportasi yang terjangkau, berkualitas tinggi, dan mudah diakses. Beberapa contoh layanan seperti itu yang sangat populer adalah Gojek.

Bagi banyak masyarakat, terutama mereka yang tinggal di kota berpenduduk padat dan yang upah bulanannya jauh dari biaya hidup, membeli kendaraan adalah sebuah pilihan. Oleh karena itu, inovasi terbaru dalam layanan transportasi ini membawa banyak solusi baru. Ada berbagai perusahaan di Indonesia yang menyediakan layanan transportasi umum berbasis elektronik, salah satu komunitas yang paling populer adalah seperti Grab dan Gojek. Aplikasi ini menyediakan berbagai layanan seperti ojek, penumpang atau barang, pemesanan 
makanan, memesan barang untuk kebutuhan Anda, dan sebagainya.

Aplikasi ini dapat diunduh di PlayStore dan Appstore. Keberadaan Gojek dengan berbagai fitur layanannya pasti dapat memberikan efek yang berbeda pada komunitas. Gojek merupakan salah satu aplikasi yang saat ini banyak digunakan oleh manusia dan setiap saatnya selalu mengalami perkembangan. Aplikasi Gojek dapat bekerja dengan baik berkat didukung dengan sistem informasi geografis yang baik, sehingga manusia dalam memanfaatkan aplikasi Gojek tidak hanyak harus mengerti tentang bagaimana penggunaan aplikasi tersebut tetapi juga harus paham bagaimana sistem informasi geografis (peta) bekerja secara online.

Oleh sebab itu, kualiatas layanan menjadi tolak ukur keberhasilan dalam menjalankan transportasi online ini. Pengguna memiliki konsekuensi dari kualitas layanan yang buruk dan penilaian mereka terhadap kualitas layanan sangat penting. Persepsi kualitas layanan adalah evaluasi subyektif dari layanan yang diberikan, berdasarkan interaksi antara pengguna dan pengguna perangkat (Eboli dan Mazzulla 2007; Zeithaml et al. 2006). Penilaian kualitas layanan melibatkan pengidentifikasian parameter layanan atau atribut yang secara langsung memengaruhi persepsi pengguna.

Parameter kualitas layanan dapat diklasifikasikan dalam dua kategori besar yaitu parameter kuantitatif dan parameter kualitatif. Parameter kuantitatif antara lain yaitu waktu perjalanan, waktu tunggu, jarak berjalan, dan lainnya. Sedangkan parameter kualitatif antara lain yaitu seberapa baik atau buruk mereka menemukan layanan (perilaku pengemudi, keselamatan dan keamanan, sistem pengumpulan tarif, pemeliharaan, dan ketersediaan informasi). Parameterparameter tersebut dapat berkembang seiring waktu seperti administrasi pengaduan, karakteristik rute, penggunaan teknologi ramah lingkungan, pengawasan orang tua, dan lainnya.

Menurut Taylor et al., (2009) persepsi pengguna tentang kualitas layanan bervariasi karena keadaan situasional (misalnya, konteks perkotaan dan pedesaan, kebutuhan pribadi pengguna, pengalaman mereka dari penyedia layanan dan penilaian mereka tentang apa yang dapat disampaikan. Memahami keragaman ini adalah tugas yang kompleks dan memerlukan pendekatan metodologis yang berbedabeda. Meskipun pendekatan berbasis survei memiliki manfaat bekerja dengan sampel besar individu.

Penelitian ini bertujuan menganalisis pemanfaatan aplikasi Gojek berbasis sistem informasi geografis khususnya mengarah kepada kualitas layanan yang diperoleh pengguna Gojek dan pemahaman pengguna Gojek dalam penggunaan sistem kordinat dalam peta lokasi aplikasi Gojek. Hal ini dikarenakan setiap konsumen pengguna aplikasi Gojek akan mendapatkan pengemudi secara acak, sehingga akan memberikan persepsi yang berbeda-beda terhadap pengguna aplikasi, sehingga perlu dikaji dengan suatu penelitian.

\section{METODE PENELITIAN \\ Lokasi Penelitian}

Penelitian ini dilakukan di Universitas Islam Sumatera Utara Fakultas Ilmu Sosial Program Studi Ilmu Komunikasi dalam jangka waktu dari bulan Januari - September 2019. Penelitian ini menggunakan pendekatan kuantitatif dan metode studi deskriptif. Metode ini merupakan suatu metode yang digunakan untuk memecahkan sekaligus menjawab suatu permasalahan yang terjadi pada masa sekarang, yang dilakukan mulai dengan pengumpulan data, klasifikasi, pengolahan data,analisis, dan membuat kesimpulan (Ali, 1982).

Penelitian ini menganalisis tentang Persepsi terhadap kualitas layanan yang 
terdiri atas kenampakan fisik, reliabilitas, responsivitas, kompetensi, kesopanan,

\section{Data Penelitian}

Populasi penelitian ini adalah mahasiswa yang masih aktif pada Program Studi Ilmu Komunikasi Fakultas Ilmu Sosial, Universitas Islam Sumatera Utara dan yang menggunakan aplikasi Gojek yaitu sebanyak 252 Orang (mahasiswa/mahasiswi), sedangkan kredibilitas, keamanan, akses, komunikasi, dan pengertian.

sampel penelitian ini adalah sebanyak 72 orang (mahasiswa/mahasiswi) yang didapatkan berdasarkan metode Proportional Stratified Sampling. Untuk lebih jelasnya populasi dan sampel dalam penelitian ini dapat dilihat pada Tabel 1 dan 2 berikut ini.

Tabel 1. Populasi Mahasiswa Ilmu Komunikasi Fakultas Ilmu Sosial UINSU Yang Menggunakan Aplikasi Gojek

\begin{tabular}{|c|c|c|c|c|c|}
\hline No. & Kelas (Angkatan) & Jumlah & No. & Kelas (Angkatan) & Jumlah \\
\hline 1. & $1-(2018)$ & 18 & 11. & $3-(2017)$ & 14 \\
\hline 2. & $2-(2018)$ & 17 & 12. & $4-(2017)$ & 8 \\
\hline 3. & $3-(2018)$ & 14 & 13. & $5-(2017)$ & 10 \\
\hline 4. & $4-(2018)$ & 16 & 14. & $6-(2017)$ & 8 \\
\hline 5. & $5-(2018)$ & 14 & 15. & 7 - (2017) & 11 \\
\hline 6. & $6-(2018)$ & 15 & 16. & 8 - (2017) & 12 \\
\hline 7. & $7-(2018)$ & 16 & 17. & Humas - (2016) & 13 \\
\hline 8. & $8-(2018)$ & 14 & 18. & Jurnalistik - (2016) & 6 \\
\hline 9. & $1-(2017)$ & 13 & 19. & Humas - (2015) & 7 \\
\hline 10. & $2-(2017)$ & 12 & 20. & Jurnalistik - (2015) & 14 \\
\hline \multicolumn{5}{|c|}{ Jumlah Populasi } & 252 \\
\hline
\end{tabular}

Sumber: Hasil Survei, 2019

Tabel 2. Cara Pengambilan Sampel Berdasarkan Pupulasi

\begin{tabular}{cccc}
\hline Angkatan & Populasi & Teknik Penarikan Sampel & Sampel \\
\hline Ilmu Komunikasi (2015) & 21 & $\frac{21 \times 72}{252}$ & 6 \\
Ilmu Komunikasi (2016) & 19 & $\frac{19 \times 72}{252}$ & 5 \\
Ilmu Komunikas (2017) & 88 & $\frac{88 \times 72}{252}$ & 25 \\
Ilmu Komunikasi (2018) & 124 & $\frac{124 \times 72}{252}$ & 36 \\
\hline
\end{tabular}

Sumber: Pengolahan Data, 2019

\section{HASIL DAN PEMBAHASAN}

Berdasarkan hasil penelitian diperoleh berbagai macam pemahaman pengguna terhadap layanan yang Jurnal Geografi Vol 12 No. 02 - 2020 diberikan oleh aplikasi Gojek. Secara umum pengguna (konsumen) menyatakan bahwa aplikasi Gojek memberikan fasilitas yang menarik, 
mudah, bagus, dan sesuai dengan kebutuhan pengguna saat ini.

\section{Persepsi Penggunaan Terhadap Kualitas Layanan Aplikasi Gojek}

Bagi kalangan mahasiswa Ilmu Komunikasi UINSU, penggunaan aplikasi Gojek menarik dan mudah untuk diakses dari segi tampilan menu dan fungsi aplikasi seperti google map dan peta lokasi sehingga memudahkan mahasiswa ketika menentukan titik lokasi penjemputan dan tujuan karena dalam aplikasi tersedia kordinat serta jalan-jalan secara jelas. Adapun peta lokasi pada aplikasi Gojek ketika menggunakannya dapat dilihat pada Gambar 1 berikut ini.

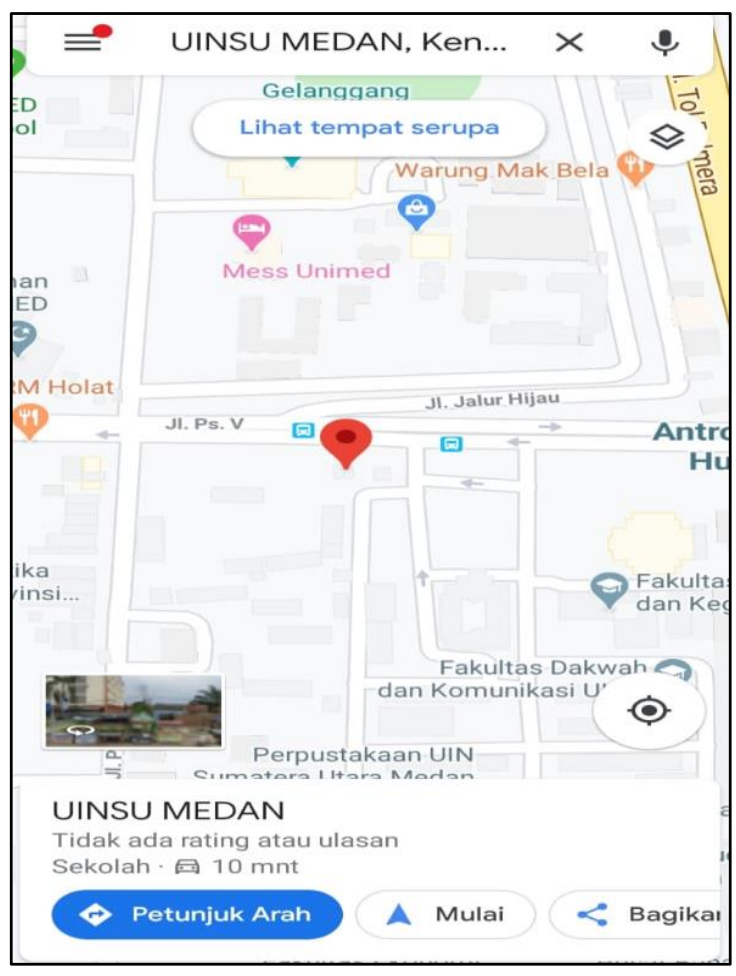

Gambar 1. Peta Lokasi Pada Aplikasi

Dari sisi kualitas pelayanan mahasiswa memberikan tanggapan yang sangat bervariasi. Namun, mayoritas responden juga menyatakan bahwa Gojek memberikan fasilitas yang sesuai dengan kebutuhan konsumen dari segi fasilitas yang telah mereka dapatkan.

Adapun kualitas layanan yang dapat dilihat yakni kenampakan fisik, reliabilitas, responsivitas, kompetensi, kesopanan, kredibilitas, keamanan, akses, komunikasi, dan pengertian. Persepsi kualitas layanan Gojek dapat dilihat pada Tabel 3 berikut.

Tabel 3. Jawaban Kemudahan Penggunaan Aplikasi Gojek

\begin{tabular}{lccc}
\hline \multicolumn{1}{c}{ Jawaban } & F & $\%$ & $\begin{array}{c}(\%) \\
\text { Kumulatif }\end{array}$ \\
\hline Tidak Mudah & 2 & 2,8 & 2,8 \\
Kurang Mudah & 4 & 5,6 & 8,3 \\
Netral & 6 & 8,3 & 16,7 \\
Mudah & 31 & 43,1 & 59,7 \\
Sangat Mudah & 29 & 40,3 & 100,0 \\
\hline \multicolumn{1}{c}{ Total } & 72 & 100,0 & \\
\hline
\end{tabular}

Sumber: Pengolahan Data, 2019

Dari Tabel 3 dapat diketahui hasil dari pertanyaan mengenai kemudahan mengakses (penggunaan) aplikasi Gojek oleh konsumen. Data penelitian pada tabel di atas menunjukkan bahwa dari total 72 responden dengan persentase $100 \%$ dapat diketahui 2 orang responden menjawab aplikasi Gojek tidak mudah untuk diakses dengan persentase 2,8\%. 4 orang menjawab kurang mudah dengan persentase $5,6 \%$ dan 6 orang menjawab netral dengan persentase $8,3 \%$. Berikutnya hasil penelitian menunjukkan bahwa 31 orang menjawab mudah dengan persentase $43,1 \%$ dan 29 orang menjawab sangat mudah dengen persentase $40,3 \%$.

Berdasarkan hasil penelitian di atas dapat ditarik kesimpulan bahwa mayoritas responden yaitu sebanyak 31 dengan persentase $43,1 \%$ orang telah mempersepsikan aplikasi Gojek mudah untuk diakses dan paling sedikit menyatakan bahwa aplikasi Gojek tidak mudah untuk diakses sebanyak 2 orang. Dimana 31 dari total responden sebanyak 72 orang menyatakan bahwa aplikasi Gojek mudah untuk diakses dari tampilan dan fungsi menu yang ada pada aplikasi. Alasannya adalah kebiasaan mahasiswa dalam menggunakan aplikasi Gojek dan paham tentang penggunaan peta lokasi penjemputan dan lokasi tujuan. Dan 
diantara responden masih didapatkan yang belum terbiasa menggunakan aplikasi Gojek dikarenakan tidak paham pada penggunaan peta pada aplikasi.

Disamping itu, sangat penting untuk mengatahui reliabilitas pengguna yang mencakup sejauh mana informasi yang diberikan oleh pengemudi Gojek menunjukkan bahwa mayoritas responden menyatakan sangat setuju jika pengemudi Gojek selalu memberikan arahan sesuai dengan standar operasional yang berlaku. Selain itu, mayoritas responden menyatakan pengemudi Gojek mengetahui dengan tepat informasi lokasi tujuan. Untuk lebih jelasnya dapat dilihat pada Tabel 4 berikut.

Tabel 4. Pengetahuan Pengemudi Gojek Dalam Menggunakan Peta Titik Lokasi Penjemputan

\begin{tabular}{cccc}
\hline Jawaban & F & $\%$ & $\begin{array}{c}(\%) \\
\text { Kumulatif }\end{array}$ \\
\hline Tidak Tahu & 1 & 1.4 & 1.4 \\
Kurang Tahu & 7 & 9.7 & 11.1 \\
Netral & 21 & 29.2 & 40.3 \\
Tahu & 28 & 38.9 & 79.2 \\
Sangat Tahu & 15 & 20.8 & 100.0 \\
\hline Total & 72 & 100.0 & \\
\hline
\end{tabular}

Sumber: Pengolahan Data, 2019

Tabel 3 merupakan tabel yang menyatakan bahwa pengemudi GOJEK mengetahui dengan tepat informasi jalan menuju lokasi tujuan. Data penelitian pada tabel di atas menunjukkan bahwa dari total 72 responden dengan persentase $100 \%$ terlihat 1 orang menjawab tidak tahu dengan persentase $1,4 \%, 7$ orang menjawab kurang tahu dengan persentase $9,7 \%$, dan 21 orang menjawab netral dengan persentase $29,2 \%$. Berikutnya hasil penelitian juga memperlihatkan bahwa 28 orang menjawab tahu dengan persentase $38,9 \%$ dan 15 orang menjawab sangat tahu dengan persentase $20,8 \%$.

Berdasarkan hasil penelitian di atas dapat ditarik kesimpulan bahwa mayoritas responden yaitu sebanyak 28 orang dengan persentase $38,9 \%$ telah mempersepsikan pengemudi Gojek memberikan fasilitas sesuai dengan kebutuhan penumpangnya dan hanya 1 orang menyatakan bahwa pengemudi Gojek tidak mengetahui dengan tepat akses jalan menuju lokasi tujuan. Adapun ketidaktahuan penggunaan peta lokasi penjemputan dan tujuan tersebut dapat dilihat pada Gambar 2 berikut ini.

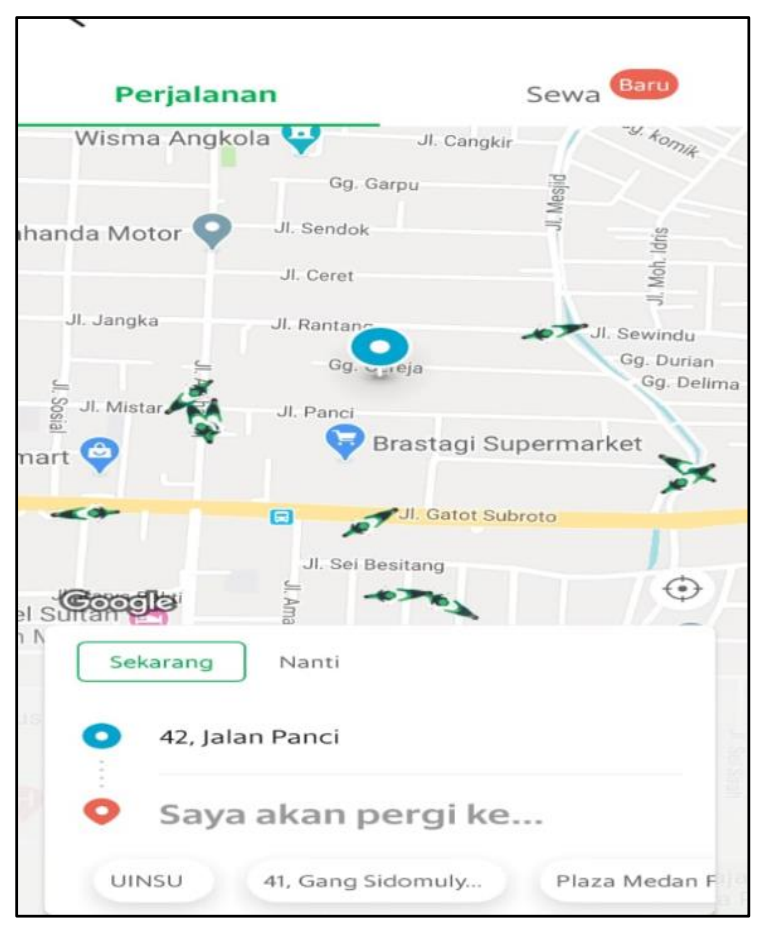

Gambar 2. Lokasi Penjemputan dan Tujuan Pengguna Gojek

Berdasarkan hasil penelitian tidak semua pengemudi mengikuti arah sesuai dengan peta yang ditampilkan pada aplikasi Gojek, hal ini dikarenakan pengemudi tidak terbiasa menggunakan peta yang ditampilkan pada aplikasi dan tidak memahami bagaimana cara membaca peta yang baik dan benar.

Pada sisi responsivitas mencakup daya tanggap provider atau kemampuan Gojek dalam menanggapi keluhan konsumen untuk mendapatkan jawaban bahwa mayoritas reponden menyatakan tanggapan atau keluhan ditanggapi dengan baik oleh pihak Gojek. Mayoritas reponden juga menyatakan sangat setuju jika pihak Gojek cepat tanggap dalam 
menanggapi keluhan pengguna (konsumen), hal ini dikarenakan pihak Gojek langsung memberikan tanggapan atau feedback terhadap keluhan yang pelanggan (konsumen) sampaikan.

Mayoritas reponden menyatakan pengemudi Gojek sangat tidak tepat waktu dalam menjemput penumpang sesuai dengan informasi yang ada di aplikasi, hal ini terjadi karena ketidakpahaman pengemudi Gojek dalam membaca informasi yang ditampilkan pada peta di aplikasi Gojek, sehingga pengemudi Gojek mencari informasi lokasi penjemputan pada sesama pengemudi Gojek. Untuk lebih tepatnya waktu yang dibutuhkan pengemudi untuk mencapai lokasi tujuan dapat dilihat pada Gambar 3 berikut ini.

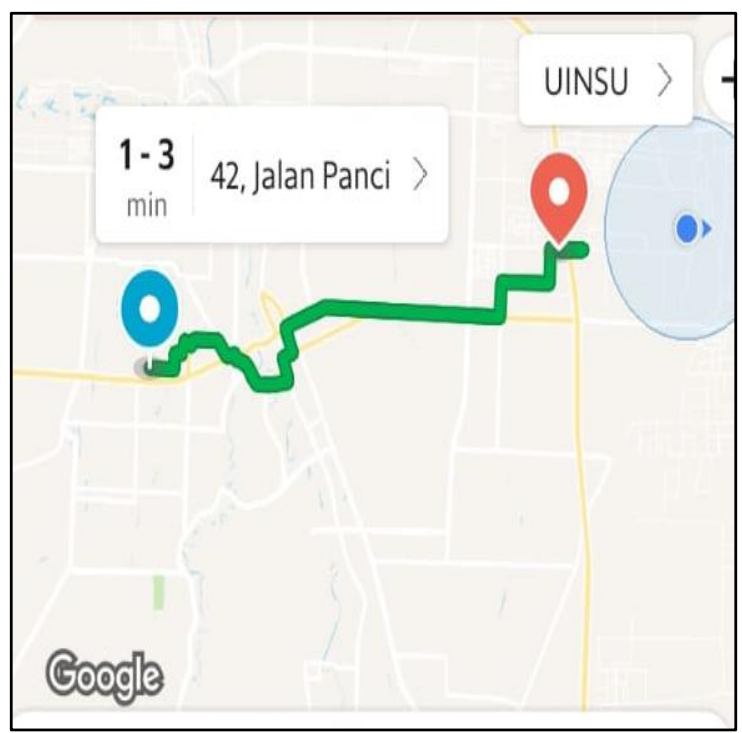

Gambar 3. Peta waktu tempuh pengemudi

Berdasarkan Gambar 3 dapat diketahui waktu tempuh oleh pengemudi, tetapi pada kenyataanya banyak yang tidak sesuai dengan waktu yang tertera pada aplikasi dan berbagai faktor lainnya seperti kemacetan dan ketidaktahuan pengemudi pada lokasi penjemputan.

Indikator lainnya yang mendukung terhadap layanan aplikasi Gojek adalah kesopanan pengemudi Gojek dalam memberikan pelayanan kepada konsumen sangat sopan, ramah, dan memiliki attitude yang baik terhadap pelanggan (konsumen), hal ini dilakukan sebagai salah satu bentuk layanan utama seorang pengemudi Gojek terhadap pelanggan, sehingga memberikan rasa aman dalam berkendara menggunakan aplikasi Gojek. Hal lainnya yang terkait dengan kredibilitas mencakup reputasi perusahaan, biaya yang dikeluarkan, dan keberadaan pengemudi Gojek selama jam kerja juga menunjukkan bahwa mayoritas responden menyatakan setuju jika konsumen lebih memilih untuk menggunakan Gojek dibandingkan transportasi online dan transportasi umum lainnya. Mayoritas responden juga menyatakan reputasi Gojek khususnya Go-Ride sebagai transportasi online sudah baik menurut persepsi pelanggan. Selain itu, mayoritas responden menyatakan biaya yang konsumen keluarkan sudah sangat sesuai dengan layanan transportasi yang diperoleh dari aplikasi Gojek.

Kemudahan informasi dalam menghubungi pelanggan sangat mudah dan mendapatkan respon yang cepat oleh pengemudi. Sedangkan komunikasi dan pengertian (understanding the customer) menunjukkan bahwa pelanggan (konsumen) menyatakan sangat baik dan bagus, hal ini dikarenakan pengemudi Gojek segera meminta maaf apabila terjadi ketidaknyamanan saat mengantarkan penumpang.

Sejalan dengan penelitian (Silalahi et al., 2017) menunjukkan bahwa persepsi kognitif menunjukkan bagaimana aliran dalam aplikasi transportasi online cocok dengan pemahaman pengguna (misalnya ketika pengguna memesan layanan transportasi online, pengguna akan mendapatkan perkiraan jarak dan harga). Kognitif dimiliki oleh dimensi kontrol yang dirasakan yang mengharuskan seseorang untuk memprediksi probabilitas plot suatu peristiwa dan implikasinya. Selanjutnya juga berpendapat bahwa kontrol ini sangat penting di antara semua dimensi kontrol yang dirasakan. Kontrol ini dapat 
mengurangi ketidakpastian dan meningkatkan nilai layanan yang dirasakan oleh pengguna. Dengan persepsi kognitif memiliki bobot tertinggi, hal ini menunjukkan bahwa kualitas layanan dalam kriteria ini adalah yang terbaik dibandingkan dengan kriteria lainnya. Dalam dimensi kualitas informasi, kriteria tertimbang tertinggi adalah kegunaan konten. Kegunaan konten berarti bahwa informasi yang diberikan tepercaya, berguna, terkini, dan akurat. Kegunaan terkait dengan relevansi dan kejelasan informasi.

Penting untuk memiliki layanan dengan kegunaan konten yang tinggi. Pengguna merasa bahwa Gojek sudah memiliki kegunaan konten yang layak. Namun, perlu dicatat bahwa dalam perbandingan keseluruhan, kegunaan konten berada di peringkat sepuluh (10). Dalam dimensi kualitas sistem, kemudahan penggunaan memiliki bobot tertinggi di antara yang lainnya. Menurut Zeithaml et al., (2002) transaksi yang dilakukan di internet tampaknya lebih kompleks dan mengintimidasi pelanggan. Karena itu, kemudahan penggunaan dianggap sebagai hal yang penting. Costabile et all., (2005) berpendapat bahwa penggunaan sistem dalam lingkungan ecommerce akan meningkat jika sistem tersebut mudah digunakan dalam memenuhi kebutuhan pelanggan dan menyediakan layanan dukungan. Ini menunjukkan bahwa kemudahan penggunaan memiliki peran penting dalam menentukan kualitas layanan yang dirasakan oleh pelanggan.

Responden menganggap bahwa Gojek mudah digunakan. Salah satu faktornya adalah bahwa antar muka pengguna terus ditingkatkan oleh Gojek untuk memenuhi harapan pengguna. Sementara itu, risiko yang dirasakan, kecukupan konten, dan interaktivitas adalah tiga kriteria dengan bobot terendah di setiap dimensi yang saling menghormati. Secara keseluruhan peringkat, kompensasi, kepercayaan, dan

Jurnal Geografi Vol 12 No. 02 - 2020 risiko yang dirasakan jatuh di peringkat tiga terbawah. Hasil ini dapat digunakan oleh Gojek untuk mengidentifikasi aspek kualitas layanan mana yang masih kurang. Menurut hasil ini, kepercayaan dan risiko yang dirasakan masih menjadi masalah dalam layanan transportasi online di Indonesia.

Sara Ramos et al., (2019) mengemukakan bahwa aplikasi Gojek telah menjadi basis virtual untuk pengemudi Gojek. Basis virtual ini telah berkembang menjadi basis nyata dalam konteks yang berbeda. Internet tidak menghilangkan hubungan di antara pengemudi Gojek, sebaliknya itu mengarah pada hubungan baru. Efek gabungan dari komunitas online di platform lain, termasuk Twitter dan WhatsApp, membantu menciptakan rasa kebersamaan di antara para pengemudi Gojek. Hubungan baru ini diperkuat oleh desain.

Desain bisa menjadi tanda utama yang bisa membangkitkan semangat masyarakat. Gairah ini, sebagaimana dinyatakan oleh Benedict Anderson, mengubah individu yang berbeda menjadi komunitas yang dibayangkan dengan mengikat orang yang dapat merasa seolah-olah mereka adalah bagian dari komunitas untuk menjalin hubungan. Desain telah menjadi tanda utama bagi pengemudi Gojek, memungkinkan individu untuk merekonstruksi identitas mereka. Kami menemukan bahwa masih ada rasa solidaritas, persaudaraan, dan persahabatan antara para pengemudi Gojek yang disatukan oleh desain. Warna hijau pada jaket dan helm menjadikan Gojek perusahaan yang nyata dan formal, dan menciptakan rasa percaya dan aman.

Bagi pengemudi, hijau memiliki kekuatan untuk membawa solidaritas yang menyatukan komunitas Gojek ke dalam komunitas yang dibayangkan. Dalam konsep komunitas yang dibayangkan, sebuah totem yang dapat menyatukan orang-orang dalam kesamaan dan kebersamaan diperlukan. Desain mampu 
menghadirkan serangkaian tanda yang dapat melibatkan keinginan orang untuk membentuk sebuah komunitas.

\section{KESIMPULAN}

Perkembangan teknologi Informasi merupakan suatu pengaruh globalisasi yang dapat mengubah perilaku seseorang saat ini. Globalisasi menjadikan ruang komunikasi yang jauh menjadi dekat dengan adanya aplikasi dan konektivitas pada dunia maya, sehingga memudahkan untuk untuk berinteraksi. Khususnya pada Mahasiswa Ilmu Komunikasi FIS UINSU telah merasakan arus globalisasi tersebut. Perkembangan teknologi dan informasi saat ini telah membawa perubahan pada diri mereka terutama dalam menggunakan aplikasi pada smartphone. Pada smartphone mahasiswa didapati aplikasi Gojek sebagai sarana transportasi dalam melakukan mobilitas. Pilihan menggunakan aplikasi Gojek karena dapat menghemat efisiensi waktu, biaya dan tenaga, sehingga mahasiswa mempersepsikan aplikasi Gojek sebagai transportasi online yang bagus, baik, dan kredibel. Namun demikian, dalam pemanfaatannya masih ditemukan pengemudi yang belum mengerti dan mahir amenggunakan aplikasi peta lokasi penjemputan dan tujuan pelanggan dikarenakan belum melek terhadap penggunaan peta lokasi pada aplikasi. Alsannya adalah dikarenakan masih baru dan lebih nyaman menggunakan informasi secara manual dengan bertanya ke orang-orang daripada mengikuti titik pada peta lokasi aplikasi Gojek.

\section{DAFTAR PUSTAKA}

A. Zeithaml, V. Parasuraman, A. and L. Berry L. (1985). "Problems and Strategies in Services Marketing". Jurnal of Marketing Vol. 49. (Spring).

Ali, Muhammad. (1982). Penelitian Pendidikan Prosedur dan Strategi. Bandung: Angkasa.

Costabile, M., Raimondo, M.A. \& Miceli, G. (2002). A Dynamic Model of
Customer Loyalty. Proceedings of the 31st Annual Conference of the European Marketing Academy, 28-31 May, Braga.

Eboli, Laura, and Gabriella Mazzulla. (2007). Service quality attributes affecting customer satisfaction for bus transit. Journal of Public Transportation 10: $21-34$

Gaspersz. (2002). Total Quality Management. Jakarta: PT. Gramedia Pustaka Utama.

Kurnia. (2005). Jurnalisme Kontemporer. Jakarta: Yayasan Obor Indonesia.

Mcquail, Dennis. (2009). Mass Communication Theory. London: Stage Publication Ltd.

Rakhmat, Jalaludin. (2011). Metode Penelitian Komunikasi. Bandung: PT. Remaja Rosdakarya.

Ramos, S, et all. (2019). Perceptions of the Public Transport Service as a Barrier to the Adoption of Public Transport: A Qualitative Study. Social Science, MDPI. Soc. Sci. 2019, 8, 150;

Robbin SP, dan Judge. (2008). Perilaku Organisasi. Jakarta: Salemba Empat.

Silalahi, 2017, et al. (2017). Service Quality Analysis for Online Transportation Services: Case Study of GOJEK. 4th Information Systems International Conference 2017, ISICO 2017, 6-8 November 2017, Bali, Indonesia. Procedia Computer Science, Sciencedirect.

Sugiyono. (2012). Metode Penelitian Kuantitatif dan Kualitatif. Bandung: CV. Alfabeta.

Taylor, Brian, Douglas Miller, Hiroyuki Iseki, and Camille Fink. (2009). Nature and/or Nurture? Analyzing the Determinants of Transit Ridership across US Urbanized Areas. Transportation Research Part a Policy and Practice 43: 60-77

Tjiptono dan Fandy. (2001). Manajemen Jasa. Yogyakarta: Andi Offset.

Yin, Robert. (2015). Qualitative Research from Start to Finish, 2nd ed. New York: The Guilford Press 